Research Article

\title{
Thinking working scaffolding sharing model to improve natural science competencies for biology pre-service teachers
}

\author{
Avia Riza Dwi Kurnia a,1,*, Muslimin Ibrahim b,2, Wahono Widodo b,3 \\ a Department of Biology, Faculty of Mathematics and Science, Universitas Negeri Malang (UM) JL. Surabaya No. 06 Malang, \\ East Java, 65145 Indonesia \\ b Postgraduate Program, Department of Science, Universitas Negeri Surabaya (UNESA) JI. Lidah Wetan Surabaya, East Java, \\ 60213 Indonesia \\ ${ }^{1}$ avia.riza.fmipa@um.ac.id ${ }^{*}$; musliminibrahim@unesa.ac.id; ${ }^{3}$ wahonowidodo@unesa.ac.id \\ ${ }^{*}$ Corresponding author
}

\begin{abstract}
ARTICLE INFO
ABSTRACT

Article history

Received February 24, 2019

Revised June 15, 2019

Accepted June 22, 2019

Published July 15, 2019

\section{Keywords}

Integrated science

Pre-service teacher competencies

TWSS model

Competencies of nowadays biology pre-service teacher is an important key for the future education quality. This article aimed to discuss the effectiveness of Thinking Working Scaffolding Sharing (TWSS) model implementation in Department of Biology UM. This quantitative descriptive study used learning outcomes (professional and pedagogical competencies), attitudes, and group activity of biology pre-service teacher as determinant factors of the TWSS model effectiveness. The instrument to collect the data for those parameters were product assessment and observation sheet. Universitas Negeri Malang assessment guideline was utilized to determine the pre-service teachers' competencies; meanwhile, the percentage calculation was employed as the data analysis procedure to proceed the data. The results informed: 1) the mean values of learning outcomes for professional and pedagogical competencies were 94 and 74 , respectively; 2) $92 \%$ of students showed individual responsibility in completing their tasks (in which $46 \%$ was categorized as 'excellent' and the other $46 \%$ was considered as 'good'); 3) $85 \%$ of students performed excellent attitude in their group work. Therefore, the implementation of TWSS model is effective to improve natural science competencies for biology pre-service teacher.

Copyright $\odot 2019$, Kurnia et al This is an open access article under the CC-BY-SA license

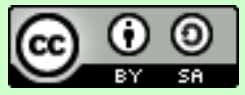

How to cite: Kurnia, A. R. D., Ibrahim, M., \& Widodo, W. (2019). Thinking working scaffolding sharing model to improve natural science competencies for biology pre-service teachers. JPBI (Jurnal Pendidikan Biologi Indonesia), 5(2), 325-334. doi: https://doi.org/10.22219/jpbi.v5i2.7742
\end{abstract}

\section{INTRODUCTION}

Science teacher should be able to master a variety of competencies, one of which is of professional competence (Hakim, 2015; Harrell, 2010; Kachalov et al., 2015). Professionally competent science teachers are characterized by their ability to master the material, structure, and scientific mindset that supports the subjects they teach (Menteri Pendidikan Nasional, 2007). An understanding of the science concept is essential 
for every science teacher (Ghazi, Shahzada, Shah, \& Shauib, 2013; Kamamia, Ngugi, \& Thinguri, 2014) so that they can teach optimally (Philip \& Ramya, 2017). Also, they should understand the relationship between branches of science (Aslan \& Taşar, 2013) due to each branch of science is interconnected (Abdullah, Halim, \& Shahali, 2011). The teacher also comprehends the correlation between science and other subjects, such as mathematics, language, and social.

Besides having professional competence, science teachers must also have pedagogic knowledge (Bhowmik, Roy, \& Banerjee, 2013; Hakim, 2015). The reason, science teachers, should master various approaches and learning models that are most suitable for integrated science subjects (Mestrinho \& Cavadas, 2018; Ramlawati, Mun'Im, \& Yunus, 2018). With pedagogical knowledge, teachers will also be able to integrate biology, physics, chemistry, and geography. They will be able to design teaching materials and methods that are suitable for integrated science subjects (Ramlawati et al., 2018). The design will also be reflected in the learning plan. The learning plan will not be of good quality if the teacher does not understand the philosophy of integrated science. Not surprisingly, pedagogy competencies are reported to affect the academic achievement of their students (Akhyak, Idrus, \& Abu Bakar, 2013; Kane, Mishra, \& Dutta, 2016; Odumosu, Olisama, \& Fisayi, 2018).

Science teachers are also expected to implement contextual learning (Asrizal, Ali Amran, Azwar Ananda, 2017; Asrizal, Amran, Ananda, \& Festiyed, 2018). The material taught is expected to be useful for any situation, especially the situation in students' daily lives. Students will be trained to can solve everyday problems. Therefore, in the learning process, students must see real problems from various perspectives. Furthermore, students are expected to become problem solvers in the real-life problem. Therefore, teachers must be able to increase student awareness and involvement in everyday problems by implementing various integrated science material or learning model as has been implemented in several previous studies (Syifahayu, 2017; Yenni, Hernani, \& Widodo, 2017). Science teachers with professional and pedagogical competence will easily design such learning.

Unfortunately, science teachers who do not come from a science education background are usually less able to become qualified integrated science teachers. This statement is based on Sarfo (2013) study which reported that such teachers could not demonstrate good abilities in diploma examination for a science teacher. The cause of this condition is because they do not recognize pedagogical competence. As a result, they do not understand the philosophy of an integrated science curriculum. Furthermore, they are difficult to design a suitable learning plan and implementing an integrated curriculum.

Various studies have also reported problems related to implementing an integrated science curriculum. Research in Nigeria informs that many science teachers do not understand the science learning method and are unable to practice integrated science learning (Ogunkola \& Samuel, 2011). Such reports are also reported in Indonesia. In Semarang, many science lesson materials have not been compiled in an integrated manner (Sudjito, Keliat, \& Hastuti, 2018). The reason, many science teachers still do not know how to integrate science material. Another report in Banda Aceh also informed that the teacher had difficulty linking the concepts in science learning (Soewarno \& Hidayat, 2012). As a result, these teachers have not been able to implement integrated science learning in junior high school.

To overcome the problems associated with the low competency of science teachers, the implementation of teacher training programs is considered as the right solution. This statement is in line with Sarfo's statement (Sarfo, 2013), which states that professional competence and teacher pedagogy can be improved through this program so that teachers can implement the integrated curriculum well. Schleigh, Bossé, \& Lee (2011) also stated that this program is beneficial for teachers to be able to implement the integrated curriculum. These various statements further strengthen the teacher training program's contribution in improving teacher competence, as has been reported in various other studies (Gaikhorst, Beishuizen, Zijlstra, \& Volman, 2017; Kanokorn, Pongtorn, \& Somjai, 2013; Ramdhani, Ancok, Swasono, \& Suryanto, 2013). Therefore, the implementation of the appropriate learning model will optimize the lecture process in this program.

However, although it is considered necessary, research that seeks to examine the effectiveness of learning models in improving teacher competence in teacher training programs is still difficult to find. Some research focuses on the positive impact of the existence of this program in improving teacher competency (Gaikhorst et al., 2017; Kanokorn et al., 2013; Ramdhani et al., 2013; Sarfo, 2013; Schleigh et al., 2011). Several other studies in Indonesia only examine the policies that underlie the existence of this program (Disas, 2017) and evaluate the implementation of the program (Triwinarni, 2017). The only study in Indonesia that examined the application of learning models to increase the competency of pre-service science teachers in the teacher training program was Kurnia's research (Kurnia, Ibrahim, Widodo, \& Nusantara, 2018).

TWSS is a learning model developed by Kurnia et al. (2018). Based on Kurnia et al. (2018), this model can facilitate pre-service science teachers to learn and practice the design of integrated science learning. TWSS is a new learning model that can provide the opportunity for pre-service teachers to learn how to teach integrated 
science learning. The existence of a module that directs students to design integrated science learning is a hallmark of this model. In the previous research, the focus of the study still limited problem-solving skills parameters (Kurnia et al., 2018). Therefore, the purpose of this study was to examine the effectiveness of the TWSS model implementation in improving the professional and pedagogical competence of pre-service science teachers in the teacher professional program.

\section{METHOD}

This quantitative descriptive study was conducted at the Biology Department, Universitas Negeri Malang (UM) by involving two research classes, i.e., $\mathrm{C}$ and $\mathrm{C} 1$ class. Each class consists of 13 students, where class $\mathrm{C}$ is divided into three groups $(\mathrm{C} 1, \mathrm{C} 2, \mathrm{C} 3)$, so in class $\mathrm{C} 1(\mathrm{C} 1.1, \mathrm{C} 1.2, \mathrm{C} 1.3)$. The study was conducted for one semester from January to May 2017. The course "Development of Middle School Science Curriculum" was chosen as a subject in this study. This course is held in two meetings/week.

The research was focused on looking at the effectiveness of applying the TWSS model in improving the competence of prospective teachers who are not of science education background. TWSS is a four-phase learning model. First, the thinking phase, the pre-service teacher works independently. Second, the working phase, the pre-service teacher works in their respective groups. Third, the scaffolding phase, pre-service teachers will be helped to solve the difficulties they face. Fourth, sharing phase, the pre-service teacher was facilitated for discussion by involving all groups in the class. In the scaffolding phase, there was two assistance provided for pre-service teachers, i.e., expert guidance and module provision. In previous research, five modules have been developed to help pre-service teachers improve their competencies. In this study, the modules studied are limited to module 1. The competency description of Module 1 is presented in Table 1.

Table 1. Competency description of Module 1

\begin{tabular}{|c|c|}
\hline Code & Standard Knowledge Competency - Graduate Achievement \\
\hline D & $\begin{array}{l}\text { Understanding concepts, and scientific mindset that supports the subject matter taught. } \\
\text { Knowledge Base Competency - Full Outcome }\end{array}$ \\
\hline D.1 & $\begin{array}{l}\text { Understand the relationship between various branches of science in science, and the relationship of science with the } \\
\text { field of study in other fields of science. } \\
\text { Knowledge Indicators Competency Module } 1\end{array}$ \\
\hline D.1.1 & $\begin{array}{l}\text { Determines the theme and can connect the KD or the scope of the material four different subjects according to the } \\
\text { example in a multidisciplinary approach. }\end{array}$ \\
\hline D.1.2 & $\begin{array}{l}\text { Identifies Basic Competencies or the material scope and can describe connections between } 3 \text { different subjects } \\
\text { according to the example of a transdisciplinary approach. } \\
\text { Skills Competency Standards - Graduate Achievement }\end{array}$ \\
\hline C & $\begin{array}{l}\text { Understanding the foundation and principles of the development and planning of the junior high school science } \\
\text { curriculum } \\
\text { Basic Skills Competency Module } 1\end{array}$ \\
\hline C.2 & $\begin{array}{l}\text { Able to design, process, and organize the integrated curriculum between science and other fields of study in the field of } \\
\text { science. } \\
\text { Skills Indicators Competency Module } 1\end{array}$ \\
\hline C.2.1 & Arrange a basic description of cross-disciplinary four learning in a multidisciplinary approach according to the example \\
\hline C.2.2 & Able to develop learning points into one science material and one other subject matter according to the example. \\
\hline C.2.3 & Design real-world problem-based learning with a transdisciplinary approach according to the example. \\
\hline
\end{tabular}

Table 2. Scoring rubric of individual attitude

\begin{tabular}{llc}
\hline & \multicolumn{1}{c}{ Indicators } & Score \\
\hline 1. & Participate in learning carelessly (Poor) & 1 \\
2. & There are unfinished questions two for maximum (Moderate) & 2 \\
3. & There are unfinished questions one for maximum (Good) & 3 \\
4. & Responsible for the task individually and well done (Excellent) & 4 \\
\hline
\end{tabular}

In this study, the parameters used to determine the effectiveness of TWSS are learning outcomes, attitudes, and group activity. The two components of learning outcomes observed were professional and pedagogic competencies of pre-service teachers. Product assessment and observation sheet were used as instruments for collecting data during research. Product assessment was used to collect learning outcomes, while observation sheets were for attitudes and group activity. Attitude competency assessment refers to the Indonesian National Qualification Framework. In more detail, the attitude assessment rubric and group activity indicators are presented in Table 2 and Table 3, respectively. Furthermore, the scores obtained by the pre- 
service teacher were matched with the criteria presented in Table 4 . These criteria are based on the assessment guidelines used by UM. This guidelines is used by all lecturers in determining the students' academic achievement at this institution. The TWSS model is declared effective if the pre-service teacher gets a minimum value of $C$.

Table 3. Social aspects indicators

Indicators Score

Focus on the task 1

Actively discuss or speak to others but still in the context of the task

Attention to others (reprimand / encourage group work) for the completion of the task

Table 4. UM appraisal guidance

\begin{tabular}{ccc} 
Mastery Level & Criteria & Score \\
$85 \%-100 \%$ & A & 4,00 \\
$80 \%-84 \%$ & A- & 3,70 \\
$75 \%-79 \%$ & B+ & 3,30 \\
$70 \%-74 \%$ & B & 3,00 \\
$65 \%-69 \%$ & B- & 2,70 \\
$60 \%-64 \%$ & C+ & 2,30 \\
$55 \%-59 \%$ & C & 2,00 \\
$40 \%-54 \%$ & D & 1,00 \\
$0 \%-39 \%$ & E & 0 \\
\hline
\end{tabular}

\section{RESULTS AND DISCUSSION}

Professional and pedagogical competencies are the two main competencies that must be mastered by science teachers. In this study, professional competence is manifested in the ability of students to design materials in an integrated manner, while pedagogical competence is realized in the form of developing teaching materials and learning plans. Based on the results of the study, the average professional competence of preservice teachers was 30 (maximum score of 36 ). On the other hand, the average pedagogic competence of pre-service teachers was 31 (maximum score of 58). Therefore, the achievement of professional and pedagogical competence of pre-service teachers was $83 \%$ and $53 \%$, respectively. After the scaffolding phase, the two competencies have increased. Increasing professional and pedagogical competencies were from $83 \%$ to $94 \%$ and from $53 \%$ to $74 \%$, subsequently.

Beside competencies that have been informed, student attitudes and activities during group work were also measured in this study. Measuring parameters of student attitudes was based on the effort to complete the task. As a result, $46 \%$ of teacher candidates were included in the "excellent" category, while $46 \%$ were in the "good" category. Thus, $92 \%$ of pre-service teachers were considered responsible for their independent duties. Furthermore, based on observations, $85 \%$ of students showed an enthusiastic and tolerant attitude in group work. If students are responsible for their tasks, they will be confident and enthusiastic in group work. In more detail, the data of the two parameters are presented in Table 5.

Table 5. Achievement of attitude competencies

\begin{tabular}{lllll}
\hline Variables & Criteria & Criteria & $\sum \mathbf{S}$ & $\sum \mathbf{S} \%$ \\
\hline The attitude of individual responsibility & Excellent & $\mathrm{A}$ & 12 & 46 \\
& Good & $\mathrm{B}$ & 12 & 46 \\
The enthusiastic \& tolerant attitude in teamwork & Excellent & $\mathrm{A}$ & 22 & 85 \\
\hline
\end{tabular}

$\mathrm{n}=$ total students $26 . \Sigma \mathrm{S} \quad=$ number of students. $\sum \mathrm{S} \%$ = number in percentage

Based on the overall data obtained, the TWSS model is considered to have the potential to improve the competence and attitudes of pre-service teachers optimally. Through the implementation of TWSS, pre-service science teachers can learn, practice, and obtain assistance in understanding learning and integrated science curriculum. The reason is that various learning experiences designed in the TWSS model can facilitate preservice teachers to achieve these various competencies. 
The first learning activity in the TWSS model is learning activities carried out by each pre-service teacher independently. In TWSS, this learning activity is known as the thinking phase. At this phase, Students practice an attitude of responsibility and active learning individually. Piaget's constructivism theory supports this phase. If students are actively involved in obtaining information, students can construct their knowledge (Bada, 2015). This is also supported by brain-based learning theories, which states that if students can actively participate in learning, they will be more eager to learn (Cave, Ludwar, \& Williams, 2006).

Based on several previous reports, the activities carried out by pre-service teachers during thinking phase activities were also considered to contribute well in improving their competence, such as Syafitri (2017) research. In his research, Syafitri (2017) informs that giving questions can improve the students' performance. Other reports also inform that student performance will also increase if learning activities provide opportunities for students to learn independently (Nahdliyati, Parmin, \& Taufiq, 2016).

The next learning activity is the working phase. In this phase, pre-service teachers conduct discussion activities with members of their respective groups. The working phase is the group discussion stage. They are working phase allows students to communicate and express their ideas in group discussions. Group work is a learning activity that has been reported to have a positive impact on learning. This learning activity is reported to be effective in increasing students' motivation (Costley \& Lange, 2018; Sainsbury \& Walker, 2009) and academic performance (Vrioni, 2011) and achievement (Alfares, 2017; Tolessa, Sorale, \& Sultan, 2017). Group work is also seen as more supportive of student development compared to solitary work. Moreover, group work is also considered as an incentive for learning (Chiriac, 2014).

After the working phase, the scaffolding phase is carried out. The TWSS model assists in 2 forms, modules, and cognitive apprenticeship. Modules contain material, assignments, and evaluations that can guide students to achieve learning goals. While cognitive apprenticeship aims to facilitate students to understand the material by linking students with an expert, lecturers can also act as experts to find solutions if students have difficulty working on assignments. The existence of scaffolding in learning provides various benefits for students. This statement is based on various reports that are studying the implementation of scaffolding in learning (Dresner, De Rivera, Fuccillo, \& Chang, 2014; Malik, 2017; Thitima \& Sumalee, 2012). Therefore, in TWSS, lecturers prepare modules to help pre-service teachers master their competencies.

The existence of modules is one form of scaffolding in learning. The following research uses modules as scaffolding and makes students able to do the task well. One such study is research in Thailand, where the modules can be used to successfully complete PBL collaborative assignments (Tiantong \& Teemuangsai, 2013). Another research in Malaysia also reports that the module can help low-level elementary students in participating in remedial learning (Hasan \& Ahmad, 2018). Not surprisingly, the achievement of task completion scores for each group was able to increase after the pre-service teachers took part in the scaffolding in this study. In more detail, the values of each group before and after scaffolding are presented in Table 6 .

Table 6. Product scores of each group before and after scaffolding

\begin{tabular}{ccc}
\hline Groups & Score before scaffolding & Score after scaffolding \\
\hline C1 & 53 & 81 \\
C2 & 84 & 89 \\
C3 & 68 & 80 \\
C1.1 & 54 & 82 \\
C1.2 & 83 & 87 \\
C1.3 & 51 & 79 \\
\hline Mean & $\mathbf{6 6}$ & $\mathbf{8 0}$ \\
\hline
\end{tabular}

In this study, the application of scaffolding during TWSS implementation was limited only to the use of Module 1. The material discussed in Module 1 deals with professional competence and teacher pedagogy. Based on the competencies presented in Table 1, the competencies expected by teacher candidates after studying module 1 can master how to integrate branches of science. In the module, pre-service teachers will learn the concept of transdisciplinary material. The basic principle of the concept is that science learning must be directed to discuss environmental conditions from various scientific perspectives. Students also facilitate to studying their environmental conditions from biology, physics, and chemistry perspectives (Menteri Pendidikan dan Kebudayaan, 2013). In integrating the branches of science, teachers must implement a transdisciplinary approach that further contextualizes learning.

The principle of scaffolding in learning is to help students achieve learning objectives (Belland, 2017; Browne, Hough, \& Schwab, 2009; Malik, 2017; Sinaga \& Suhandi, 2015). The scaffolding phase is supported by Vygotsky's social constructivist theory (Malik, 2017; Shabani, Khatib, \& Ebadi, 2010). There are four important principles of Vygotsky's constructivist theory; one of them is Zone of Proximal Development (ZPD). The term refers to a condition where students are not able to master competencies if they study on their own. 
Vygotsky believed, by providing appropriate assistance, students will be able to achieve these competencies (Bozhovich, 2010; Mishra, 2013; Semmar \& Al-Thani, 2015).

Related to ZPD, Table 7 shows the tasks that the group cannot complete. Based on this study, ZPD is not only owned by individuals but can also occur in groups. Each group has different difficulties. These results are consistent with the Masters (2013) conducted a cohort study on "ICT for education" courses in the first semester for elementary school prospective students at La Trobe University

Table 7. ZPD of each groups

\begin{tabular}{|c|c|c|c|c|c|c|}
\hline Difficulties Group & C1 & C2 & C3 & C1.1 & C1.2 & C1.3 \\
\hline $\begin{array}{l}\text { 1. Not able to distinguish multidisciplinary and } \\
\text { transdisciplinary. }\end{array}$ & $\sqrt{ }$ & & & $\sqrt{ }$ & & $\sqrt{ }$ \\
\hline 2. Transdisciplinary design is too difficult & & & $\sqrt{ }$ & & & \\
\hline $\begin{array}{l}\text { 3. Transdisciplinary design is not oriented to real-world } \\
\text { problems }\end{array}$ & $\sqrt{ }$ & & & $\sqrt{ }$ & & $\sqrt{ }$ \\
\hline Difficulties in designing PBL lesson plan & $\sqrt{ }$ & $\sqrt{ }$ & $\sqrt{ }$ & $\sqrt{ }$ & $\sqrt{ }$ & $\sqrt{ }$ \\
\hline
\end{tabular}

The final step in the TWSS model is sharing phase. In the phase, class discussions are conducted. The results of working on assignments in groups are discussed in class. This phase is supported by Bandura's socio-cognitive learning theory. According to this theory, learning is the result of observing others (Harinie, Sudiro, Rahayu, \& Fatchan, 2017). Also, sharing activities are supported by Ausubel's learning theory. In this theory, if students can associate new information with the concepts they have learned, they will better master these concepts (Arends, 2012).

Besides being supported by various learning theories, sharing activities also provide some positive impacts on learning. By conducting class discussions, each group can learn what other groups have learned. Each group will listen to opinions and products from other groups. Besides, each group will also get advice from other groups. Because of these benefits, various other learning models involve sharing activities in the learning syntax, such as think-pair-share (Arends, 2012; Yusnani, 2018),

The pre-service science teacher competence is an urgent issue that must be of concern to all parties. Their competency level will determine the optimal science education in the future (Hakim, 2015). At present, Indonesia is trying to improve the quality of teachers through the teacher training program (Surya, 2016). Through the program, all prospective teachers and teachers in Indonesia are expected to be able to improve their competence. In order for the target to be achieved optimally, the application of a learning model that can effectively improve teacher competencies needs to be implemented.

Based on the discussion that has been explained, TWSS is a learning model that can improve the competence of pre-service science teachers. The existence of individual learning activities, cooperative learning activities, and scaffolding activities are the hallmarks of the TWSS model. These various learning experiences can optimize the empowerment of competency of science teacher candidates so they can facilitate to become qualified teacher candidates.

\section{CONCLUSION}

In this study, the effectiveness of the TWSS model was assessed. The results, the mean score of preservice teachers in the parameters of professional competence was 94 , while in pedagogical competence was 74. Furthermore, $92 \%$ have the responsibility in completing the tasks given, while $85 \%$ of students have an excellent attitude. The results of this study inform that the TWSS model can be recommended as a learning model that can empower the competencies of pre-service science teachers optimally. TWSS is a learning model that is still newly developed. The research that studying the model still needs to be done to explore the potential of the TWSS model further. Therefore, further research examining various other competencies, such as the 21 st Century competency for science teacher candidates, needs to be conducted.

\section{REFERENCES}

Abdullah, S. I. S. S., Halim, L., \& Shahali, E. H. M. (2011). Integration of environmental knowledge across Biology, Physics and Chemistry subject at secondary school level in Malaysia. In Procedia - Social and Behavioral Sciences (Vol. 15, pp. 1024-1028). Elsevier B.V. doi: https://doi.org/10.1016/j.sbspro.2011. 03.233 
Akhyak, Idrus, M., \& Abu Bakar, Y. (2013). Implementation of teachers pedagogy competence to optimizing learners development in public primary school in Indonesia. International Journal of Education and Research, 1(9), 1-10. Retrieved from http://www.ijern.com/journal/September-2013/10.pdf

Alfares, N. (2017). Benefits and difficulties of learning in group work in EFL classes in Saudi Arabia. English Language Teaching, 10(7), 247. doi: https://doi.org/10.5539/elt.v10n7p247

Arends, R. I. (2012). Learning to teach (Ninth). New York, USA: McGraw-Hill. Retrieved from https://books.google.co.id/books/about/Learning_to_Teach.html?id=B1trewAACAAJ\&redir_esc=y

Aslan, O., \& Taşar, M. F. (2013). How do science teachers view and teach the nature of science? a classroom investigation. Education and Science, 38(167), 65-80. Retrieved from http://egitimvebilim.ted.org.tr/ index.php/EB/article/viewFile/1323/468

Asrizal, Ali Amran, Azwar Ananda, F. (2017). Need analysis to develop adaptive contextual learning model. In Proceeding of the 2nd International Conference on Teacher Education (Vol. 1, pp. 78-83). Pekanbaru. Retrieved from https://files.osf.io/v1/resources/gxqev/providers/osfstorage/5c0d14196be62d001944e02 c?action=download\&version=1\&direct

Asrizal, A., Amran, A., Ananda, A., \& Festiyed, F. (2018). Effectiveness of adaptive contextual learning model of integrated science by integrating digital age literacy on grade VIII students. In IOP Conference Series: Materials Science and Engineering (Vol. 335). doi: https://doi.org/10.1088/1757-899X/335/1/01 2067

Bada, S. O. (2015). Constructivism learning theory: A paradigm for teaching and learning. IOSR Journal of Research \& Method in Education Ver. I, 5(6), 66-70. doi: https://doi.org/10.9790/7388-05616670

Belland, B. R. (2017). Instructional scaffolding: Foundations and evolving definition. Instructional Scaffolding in STEM Education: Strategies and Efficacy Evidence. Cham: Springer International Publishing. doi: https://doi.org/10.1007/978-3-319-02565-0

Bhowmik, M., Roy, B. B., \& Banerjee, J. (2013). Role of pedagogy in effective teaching. Basic Research Journal of Education Research and Review, 2(1), 1-5. Retrieved from http://basicresearchjournals.org/ education/pdf/Bhowmik et al.pdf

Bozhovich, E. D. (2010). Zone of proximal development. Journal of Russian \& East European Psychology, 47(6), 48-69. doi: https://doi.org/10.2753/rpo1061-0405470603

Browne, L., Hough, M., \& Schwab, K. (2009). Scaffolding: A promising approach to fostering critical thinking. Schole: A Journal of Leisure Studies \& Recreation Education, 24, 114-119. Retrieved from http:/l search.ebscohost.com/login.aspx?direct=true\&db=sph\&AN=47565351\&site=ehost-live

Cave, T., Ludwar, J., \& Williams, W. (2006). Brain-based learning. Retrieved from https://education.alberta.ca/ apps/aisi /literature/pdfs/bbased_learning.pdf

Chiriac, E. H. (2014). Group work as an incentive for learning - students' experiences of group work. Frontiers in Psychology, 5(June), 1-10. doi: https://doi.org/10.3389/fpsyg.2014.00558

Costley, J., \& Lange, C. (2018). The moderating effects of group work on the relationship between motivation and cognitive load. International Review of Research in Open and Distance Learning, 19(1), 68-90. doi: https://doi.org/10.19173/irrodl.v19i1.3325

Disas, E. P. (2017). Analisis kebijakan pendidikan mengenai pengembangan dan peningkatan profesi guru. Jurnal Penelitian Pendidikan, 17(2), 158-166. Retrieved from http://ejournal.upi.edu/index.php/JER/ article/download/8251/5184

Dresner, M., De Rivera, C., Fuccillo, K. K., \& Chang, H. (2014). Improving higher-order thinking and knowledge retention in environmental science teaching. BioScience, 64(1), 40-48. doi: https://doi.org/ 10.1093/biosci/bit005

Gaikhorst, L., Beishuizen, J. J. J., Zijlstra, B. J. H., \& Volman, M. L. L. (2017). The sustainability of a teacher professional development programme for beginning urban teachers. Cambridge Journal of Education, 47(1), 135-154. doi: https://doi.org/10.1080/0305764X.2015.1125449

Ghazi, S. R., Shahzada, G., Shah, M. T., \& Shauib, M. (2013). Teacher's professional competencies in knowledge of subject matter at secondary level in Southern Districts of Khyber Pakhtunkhwa, Pakistan. Journal of Educational and Social Research, 3(2), 453-460. Retrieved from http://citeseerx.ist.psu.edul viewdoc/download?doi=10.1.1.1007.7988\&rep=rep1\&type=pdf

Hakim, A. (2015). Contribution of competence teacher (pedagogical, personality, professional competence and social) on the performance of learning. The International Journal Of Engineering And Science, 4(2), 1-12. Retrieved from http://www.theijes.com/papers/v4-i2/Nersion-3/A42301012.pdf 
Harinie, L. T., Sudiro, A., Rahayu, M., \& Fatchan, A. (2017). Study of the Bandura's Social Cognitive Learning Theory for the entrepreneurship learning process. Social Sciences, 6(1), 1-6. doi: https://doi.org/10.116 48/j.ss.20170601.11

Harrell, P. E. (2010). Teaching an integrated science curriculum: Linking teacher knowledge and teaching assignments. Issues in Teacher Education, 19(1), 145-165. Retrieved from https://pdfs.semanticscho lar.org/7f5d/fe1415bd3d985858d389e657d6d75e998b17.pdf

Hasan, R., \& Ahmad, N. A. (2018). Conceptual framework of scaffolding literacy module to help remedial students mastering reading skills. International Journal of Academic Research in Business and Social Sciences, 8(11), 1031-1038. doi: https://doi.org/10.6007/JJARBSS/v8-i11/4982

Kachalov, N., Kornienko, A., Kvesko, R., Nikitina, Y., Kvesko, S., \& Bukharina, Z. (2015). Integrated nature of professional competence. In Procedia - Social and Behavioral Sciences (Vol. 206, pp. 459-463). Elsevier B.V. doi: https://doi.org/10.1016/j.sbspro.2015.10.083

Kamamia, L. N., Ngugi, N. T., \& Thinguri, R. W. (2014). To establish the extent to which the subject mastery enhances quality teaching to student-teachers during teaching practice. International Journal of Education and Research, 2(7), 641-648. Retrieved from http://www.ijern.com/journal/July-2014/51.pdf

Kane, S. N., Mishra, A., \& Dutta, A. K. (2016). Teacher Pedagogical Content Knowledge (PCK) and students' reasoning and wellbeing. In Journal of Physics: Conference Series (Vol. 755). doi: https://doi.org/ 10.1088/1742-6596/755/1/011001

Kanokorn, S., Pongtorn, P., \& Somjai, M. (2013). Teacher development program to enhance learning competency for small primary schools in Thailand. In Procedia - Social and Behavioral Sciences (Vol. 69, pp. 1052-1058). Elsevier B.V. doi: https://doi.org/10.1016/j.sbspro.2012.12.032

Kurnia, A. R. D., Ibrahim, M., Widodo, W., \& Nusantara, T. (2018). Multidisciplinary and transdisciplinary design to teach problem solving skills. In Advances in Social Science, Education and Humanities Research (Vol. 218, pp. 161-166). Atlantis Press. doi: https://doi.org/10.2991/icomse-17.2018.29

Malik, S. A. (2017). Revisiting and re-representing scaffolding: The two gradient model. Cogent Education, 4(1), 1-13. doi: https://doi.org/10.1080/2331186X.2017.1331533

Masters, J. (2013). Scaffolding pre-service teachers representing their learning journeys with eportfolios. Journal of Learning Design, 6(1), 1-9. doi: https://doi.org/10.5204/jld.v6i1.115

Menteri Pendidikan dan Kebudayaan. Peraturan menteri pendidikan dan kebudayaan tentang kerangka dasar dan struktur kurikulum sekolah menengah pertama/madrasah tsanawiyah (2013). Indonesia. Retrieved from http://simpuh.kemenag.go.id/regulasi/permendikbud_68_13_lampiran.pdf

Menteri Pendidikan Nasional. Standar kualifikasi akademik dan kompetensi guru, Pub. L. No. 16 (2007). Indonesia. Retrieved from http://vervalsp.data.kemdikbud.go.id/prosespembelajaran/file/Permendiknas No 16 Tahun 2007.pdf

Mestrinho, N., \& Cavadas, B. (2018). Innovation in teacher education: An integrative approach to teaching and learning science and mathematics. Proceedings, 2(21), 1343. doi: https://doi.org/10.3390/proceed ings2211343

Mishra, R. K. (2013). Vygotskian perspective of teaching-learning. Innovation: International Journal of Applied Research, 1(1), 21-28. Retrieved from http://ijar.publicationsupport.com/docs/paper/22.pdf

Nahdliyati, R., Parmin, P., \& Taufiq, M. (2016). Efektivitas pendekatan saintifik model project based learning. Unnes Science Education Journal, 5(2), 1227-1234. https://doi.org/10.15294/usej.v5i2.12146

Odumosu, Olisama, \& Fisayi, A. (2018). Teachers' content and pedagogical knowledge on students' achievement in algebra. International Journal of Education and Research, 6(3), 83-94. Retrieved from https://www.ijern.com/journal/2018/March-2018/11.pdf

Ogunkola, B., \& Samuel, D. (2011). Science teachers' and students' perceived difficult topics in the integrated science curriculum of lower secondary schools in Barbados. World Journal of Education, 1(2), 17-29. doi: https://doi.org/10.5430/wje.v1n2p17

Philip, M. P., \& Ramya, K. (2017). Professional competencies for effective teaching learning process. International Journal of Trend in Research and Development (IJTRD), (Special Issue), 25-29. Retrieved from http://www.ijtrd.com/papers/lJTRD12201.pdf

Ramdhani, N., Ancok, D., Swasono, Y., \& Suryanto, P. (2013). Teacher quality improvement program: empowering teachers to increasing a quality of Indonesian's education. In Procedia - Social and Behavioral Sciences (Vol. 69, pp. 1836-1841). Elsevier B.V. doi: https://doi.org/10.1016/j.sbspro.2012. 12.134 
Ramlawati, Mun'Im, A., \& Yunus, S. R. (2018). Improving pedagogical competences of prospective science teachers to develop learning materials through jigsaw cooperative model. In Journal of Physics: Conference Series (Vol. 1028) doi: https://doi.org/10.1088/1742-6596/1028/1/012209

Sainsbury, E., \& Walker, R. (2009). Motivation, learning and group work-the effect of friendship on collaboration. In UniServe Science Proceedings (pp. 118-124). Retrieved from http://openjournals.library.usyd.edu.au/index.php/IISME/article/view/6213

Sarfo, S. (2013). The relation between teacher trainees' background in science and success in the end of first year first semester integrated science examination (a case study at St . Louis College of Education , Kumasi ). Merit Research Journal of Education and Review, 1(2), 50-57. Retrieved from https://www.meritresearchjournals.org/er/content/2013/March/Sarfo.pdf

Schleigh, S. P., Bossé, M. J., \& Lee, T. (2011). Redefining curriculum integration and professional development: In-service teachers as agents of change. Current Issues in Education, 14(3), 1-14. Retrieved from https://cie.asu.edu/ojs/index.php/cieatasu/article/view/693

Semmar, Y., \& Al-Thani, T. (2015). Piagetian and Vygotskian approaches to cognitive development in the kindergarten classroom. Journal of Educational and Developmental Psychology, 5(2), 1-7. doi: https://doi.org/10.5539/jedp.v5n2p1

Shabani, K., Khatib, M., \& Ebadi, S. (2010). Vygotsky's zone of proximal development: instructional implications and teachers' professional development. English Language Teaching, 3(4), 237-248. doi: https://doi.org/10.5539/elt.v3n4p237

Sinaga, P., \& Suhandi, A. (2015). The effectiveness of scaffolding design in training writing skills Physics teaching materials. International Journal, 8(1), 19-34. Retrieved from https://eric.ed.gov/?id=EJ1085295

Soewarno, S., \& Hidayat, A. (2012). The implementation of integrated science learning in junior high schools in Banda Aceh. Jurnal Serambi IImu, 13(1). doi: https://doi.org/10.32672/si.v13i1.1042

Sudjito, D. N., Keliat, N. R., \& Hastuti, S. P. (2018). Integrated science learning using scientific approach in junior high schools in Semarang Regency. Indonesian Journal of Science and Education, 2(1), 69-74. doi: https://doi.org/10.31002/ijose.v2i1.583

Surya, P. (2016). Student teacher recruitment in Indonesia: An initial step to promote teacher professionalism and teaching professionalization. In Proceedings of the 6th International Conference on Educational, Management, Administration and Leadership (Vol. 14, pp. 457-462). Paris, France: Atlantis Press. doi: https://doi.org/10.2991/icemal-16.2016.94

Syafitri, R. (2017). Meningkatkan tanggung jawab belajar melalui strategi giving questions and getting answers pada siswa. Jurnal Penelitian Dan Pengembangan Pendidikan, 1(2), 57-63. doi: https://doi.org/10.23887/jppp.v1i2.12623

Syifahayu. (2017). Inquiry-based integrated science education: implementation of local content "soil washing" project to improve junior high school students' environmental literacy. Journal of Physics: Conference Series, 812(1), 012082 doi: https://doi.org/10.1088/1742-6596/812/1/012082

Thitima, G., \& Sumalee, C. (2012). Scientific thinking of the learners learning with the knowledge construction model enhancing scientific thinking. In Procedia - Social and Behavioral Sciences (Vol. 46, pp. 37713775). doi: https://doi.org/10.1016/j.sbspro.2012.06.144

Tiantong, M., \& Teemuangsai, S. (2013). The four scaffolding modules for collaborative problem-based learning through the computer network on moodle Ims for the computer programming course. International Education Studies, 6(5), 47-55. doi: https://doi.org/10.5539/ies.v6n5p47

Tolessa, M. D., Sorale, J. E., \& Sultan, A. (2017). Student perception on group work and group assignments in classroom teaching: The case of Bule Hora university second year biology students, South Ethiopia: An action research. Educational Research and Reviews, 12(17), 860-866. doi: https://doi.org/10.5897/ err2016.3006

Triwinarni, E. (2017). Evaluasi program Pendidikan Profesi Guru (PPG) Pendidikan Agama Islam di UIN Sunan Kalijaga Yogyakarta. In Prosiding Interdisciplinary Postgraduate Student Conference (pp. 219223). Retrieved from http://repository.umy.ac.id/handle/123456789/8545

Vrioni, R. (2011). Effects of group learning on the academic performance of university students. Problems of Education in the 21st Century, 33, 111-. Retrieved from http://www.scientiasocialis.lt/pec/node/files/pdf/ vol33/111-117.Vrioni_Vol.33.pdf 
Yenni, R., Hernani, \& Widodo, A. (2017). The implementation of integrated science teaching materials based socio-scientific issues to improve students scientific literacy for environmental pollution theme. In AIP Conference Proceedings (Vol. 1848). AIP Publishing. doi: https://doi.org/10.1063/1.4983970

Yusnani, Y. (2018). Theoretical perspectives on cooperative learning. In KnE Social Sciences (Vol. 3, pp. 976-986). https://doi.org/10.18502/kss.v3i4.2005 